\title{
Harms Associated with cellular Towers (CDMA Vs GSM)
}

\author{
${ }^{1}$ Manish Tripathi, ${ }^{2}$ Er.Anil Kumar, ${ }^{3}$ Prof.A.K.Jaiswal, ${ }^{4}$ Er.Ashish.X. Das
}

\begin{abstract}
The use of mobile phone is increasing enormously, and hence has become a subject of recent interest and study, due to use of electromagnetic (EM) wave in the microwave range and produces radiation. Various physiological studies have found that the excessive radio frequency $(R F)$ wave exposure affects the biological systems negatively and depends on source's characteristics as modulation (continuous wave or pulsed), electric and magnetic-field strengths, power density, frequency, and duration of exposure in near or far zone. The fact that this radiation is unseeable, nonphysical, and passes through our bodies without our cognition makes it even more restraining. Global System for Mobile Communications (GSM) and Code Division Multiple Access (CDMA) are the two most common cellular communication technologies.
\end{abstract}

\section{Introduction:}

EM radiation is a form of energy and travels through space hence exhibits wave-like behaviour. EM wave has electric (E) and magnetic (M) field components oscillating in perpendicular phase and direction of energy propagation is perpendicular to both. EM radiation is classified into ionizing and non-ionizing radiation, on the basis of its capability of ionizing atoms and hence breaking chemical bonds. Non-ionizing radiation may cause two possible hazards: electrical and biological ${ }^{[1]}$. Very high power EM radiation can have strong electric currents enough to create electrical arcs as induced voltage is greater than the breakdown voltage of the surroundings. The sparks can ignite the flammable gases or materials, leading to an explosion. The other effect of EM radiation is dielectric heating in biological aspects. Weaker non-thermal EM fields including weak Extremely Low Frequency fields ${ }^{[2][3]}$ and modulated RF and microwave fields ${ }^{[4]}$ leads to complex biological effects. A magnetic field induces circulating currents within the human body and the strength depends on the intensity of the striking magnetic field. The biological process is affected by the stimulation of nerves and muscles caused by these currents. The functions of human body cells changes due to exposure of EM wave as sequence of events which results into some disorder or disease ${ }^{[5]}$.

Based on various biological studies and investigations the EM wave radiation's effects are classified in to 2 groups: Thermal and Non Thermal.

The EM wave induces the rotation of the polar molecules leads to Thermal effect which heats up the user's head surface. Such heat produced is less than the exposure to direct sunlight and disposed of by local blood circulation. This temperature regulation mechanism is not possible in cornea and may be cause of cataract, depending on the SAR values ${ }^{[6]}$.

The Non-thermal effect due to normal cellular use causes temperature increment and hence metabolic cell stress but is compensated by thermo receptor molecules containing stress proteins in cells to protect from heat shock ${ }^{[7]}$. As the stress proteins occurs for both ELF and RF, having different energy levels ${ }^{[8]}$ are unaffected by thermal effects. It has various symptoms like burning sensations in the skin of the head, headaches, dizziness, fatigue, disturbances to sleep and digestive systems, loss of mental attention to react and memory retentiveness ${ }^{[9]}$.

\section{Comparison of emitted power from GSM and CDMA cell sites}

The level of EM radiation is increasing worldwide with the users of mobile phone ${ }^{[10]}$. In India, radiation norms for safe power density of f/200, where frequency (f) is in $\mathrm{MHz}$ is adopted, given by ICNIRP. The ICNIRP has clearly stated for simultaneous exposure to multiple frequencies, the sum of all the radiations must be considered. Yet, in India, it is applied to individual carrier, so the radiation level may exceed over the limit, prescribed by ICNIRP norms, depends upon the total number of transmitters applied in that area. The ICNIRP has provided the exposure limits ${ }^{[11]}$ for general public living near the towers and facing this radiation 24 hours a day, as given in table 2.1 


\begin{tabular}{|r|l|l|}
\hline $\begin{array}{l}\text { Frequency( } \\
\text { MHz) }\end{array}$ & $\begin{array}{l}\text { Electric } \\
\text { field } \\
\text { Strength,E } \\
(\mathrm{V} / \mathrm{M})\end{array}$ & $\begin{array}{l}\text { Power } \\
\text { Density,S } \\
\text { (W/M2) }\end{array}$ \\
\hline 900 & 41 & 4.5 \\
\hline 1800 & 58 & 9 \\
\hline 2000 & 61 & 10 \\
\hline
\end{tabular}

Table 2.1 ICNIRP exposure limits for the general public

Following are the tables containing data from CDMA and GSM cell towers

\begin{tabular}{|r|r|r|r|r|r|r|}
\hline $\begin{array}{c}\text { Frequency } \\
(\mathbf{M H z})\end{array}$ & $\begin{array}{c}\text { Antenna } \\
\text { Gain } \\
(\mathbf{d B i})\end{array}$ & $\begin{array}{c}\text { Antenna } \\
\text { Height } \\
(\mathbf{m})\end{array}$ & $\begin{array}{c}\text { Distance } \\
\text { from } \\
\text { Antenna } \\
(\mathbf{m})\end{array}$ & $\begin{array}{c}\text { EIRP } \\
(\mathbf{d B m})\end{array}$ & $\begin{array}{c}\text { Total } \\
\text { EIRP } \\
\text { (Watt) }\end{array}$ & $\begin{array}{c}\text { Calculated } \\
\text { Power } \\
\text { Density as } \\
\text { \% of } \\
\text { ICNIRP } \\
\text { LIMIT }\end{array}$ \\
\hline 850 & 16.5 & 38 & 0 & 56.43 & 879.10 & 2.92 \\
\hline 850 & 16.5 & 38 & 5 & 56.43 & 879.10 & 2.87 \\
\hline 850 & 16.5 & 38 & 10 & 56.43 & 879.10 & 2.73 \\
\hline 850 & 16.5 & 38 & 15 & 56.43 & 879.10 & 2.52 \\
\hline 850 & 16.5 & 38 & 20 & 56.43 & 879.10 & 2.29 \\
\hline 850 & 16.5 & 38 & 25 & 56.43 & 879.10 & 2.04 \\
\hline 850 & 16.5 & 38 & 30 & 56.43 & 879.10 & 1.80 \\
\hline
\end{tabular}

Table $2.2 \%$ of ICNIRP limits of CDMA cell tower.

\begin{tabular}{|r|r|r|r|r|r|r|}
\hline $\begin{array}{r}\text { Frequency } \\
(\mathbf{M H z})\end{array}$ & $\begin{array}{c}\text { Antenna } \\
\text { Gain } \\
(\mathbf{d B i})\end{array}$ & $\begin{array}{c}\text { Antenna } \\
\text { Height } \\
(\mathbf{m})\end{array}$ & $\begin{array}{c}\text { Distance } \\
\text { from } \\
\text { Antenna } \\
(\mathbf{m})\end{array}$ & $\begin{array}{c}\text { EIRP } \\
(\mathbf{d B m})\end{array}$ & $\begin{array}{c}\text { Total } \\
\text { EIRP } \\
\text { (Watt) }\end{array}$ & $\begin{array}{c}\text { Calculated } \\
\text { Power } \\
\text { Density as } \\
\text { \% of } \\
\text { ICNIRP } \\
\text { IIMIT }\end{array}$ \\
\hline 1800 & 17 & 28 & 0 & 57.06 & 919.39 & 2.65 \\
\hline 1800 & 17 & 28 & 5 & 57.06 & 919.39 & 2.57 \\
\hline 1800 & 17 & 28 & 10 & 57.06 & 919.39 & 2.35 \\
\hline 1800 & 17 & 28 & 15 & 57.06 & 919.39 & 2.06 \\
\hline 1800 & 17 & 28 & 20 & 57.06 & 919.39 & 1.76 \\
\hline 1800 & 17 & 28 & 25 & 57.06 & 919.39 & 1.48 \\
\hline 1800 & 17 & 28 & 30 & 57.06 & 919.39 & 1.24 \\
\hline
\end{tabular}

Table $2.3 \%$ of ICNIRP limits of GSM cell tower.

The above data are collected from CDMA and GSM (operator: RCOM) cell sites with antenna height of 38 and 28 meters respectively.

Tool used: NEMO drive test kit to measure EIRP $(\mathrm{dBm})$.

To calculate Total EIRP (watt) of single sector;

GSM (1800MHz): $\operatorname{EIRP}_{\text {(watt) }}+\left(\mathrm{EIRP}_{(\text {watt }} * .81 *(\right.$ No. of TRX configured -1$\left.)\right)$

CDMA $(\mathbf{8 5 0 M H z}):$ EIRP $_{(\text {watt })}+\left(\right.$ EIRP $_{\text {(watt })} *($ No. of TRX configured-1) $)$

Power Density is calculated as; $\mathbf{S}=(2.56 / 4 \pi) *\left(\right.$ Total EIRP $\left._{(\text {watt }} /\left(\mathrm{h}^{2}+\mathrm{d}^{2}\right)\right)$

Where ' $h$ ' $=$ height of antenna and'd' = distance from antenna.

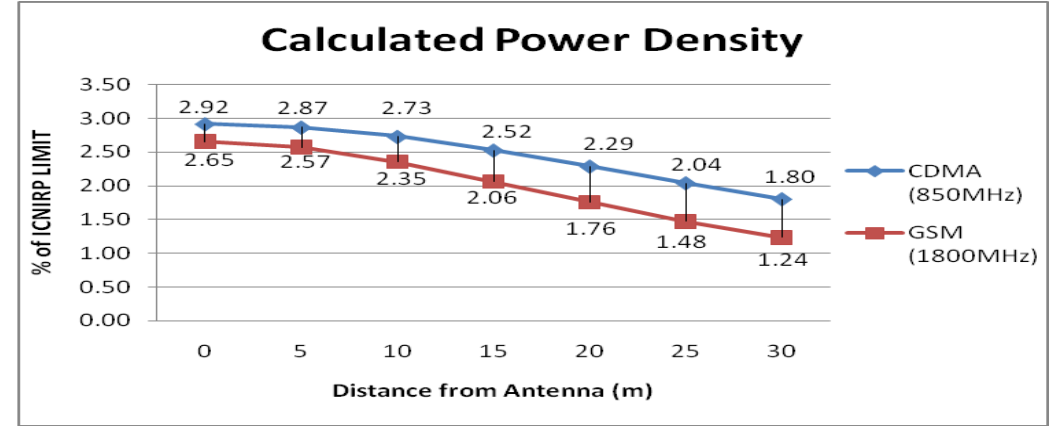

Fig.2.4 \% of ICNIRP limits CDMA Vs GSM

\section{Conclusion:}

Analyses shows the effect of mobile radiations in CDMA technology is more than the GSM at the same Tx power $(38 \mathrm{dBm})$; yet both the emitted powers are under control as per ICNIRP limit. But as shown in this study, with every technology invented to facilitate human beings, there come certain hazards as EM radiation is everywhere. The only way to beat these negative aspects of new technologies is again, a new but better technology. Expectations of more wireless communication services are raising the artificial EM radiations. It is ongoing process and being improved. Scientists and engineers must develop better and safer wireless systems and devices to radiate much lower power and make technology a real boon.

\section{References:}

[1] Wikipedia. [online] available at: en.wikipedia.org/wiki/Electromagnetic_radiation

[2] Delgado JM, Leal J, Monteagudo JL, Gracia MG (1982). "Embryological changes induced by weak, extremely low frequency electromagnetic fields". Journal of Anatomy 134 (3).pg: 533-51.

[3] Harland JD, Liburdy RP (1997). "Environmental magnetic fields inhibit the antiproliferative action of tamoxifen and melatonin in a human breast cancer cell line". Bioelectromagnetics 18, pg: 555-62.] 
[4] Aalto S, Haarala C, Brück A, Sipilä H, Hämäläinen H, Rinne JO (July 2006). "Mobile phone affects cerebral blood flow in humans". Journal of Cerebral Blood Flow and Metabolism 26 (7).pg: 885-90.

[5] 7 18th Int. Crimean Conference "Microwave Telecommunication Technology" (2008). 8-12 September, Sevastopol, Crimea, Ukraine.

[6] International Commission on Non-Ionizing Radiation Protection (April 1998). "Guidelines For Limiting Exposure To Time-Varying Electric, Magnetic, And Electromagnetic Fields (up to $300 \mathrm{GHz}$ )" (PDF). Health Physics 74 (4): 494505. PMID 9525427 . http://www.icnirp.de/documents/statgdl.pdf . Retrieved 2010-03-28.

[7] Glaser, Roland (December 2005). "Are thermoreceptors responsible for "non-thermal" effects of RF fields?" (PDF). Edition Wissenschaft (Bonn, Germany: Forschungsgemeinschaft Funk) (21). OCLC 179908725. http://www.fgf.de/publikationen/edition-wissenschaft/Edition_Wissenschaft_Nr21.pdf . Retrieved 2008-01-19.

[8] Blank, Martin; Goodman, Reba (2009). "Electromagnetic fields stress living cells". Pathophysiology 16 (2-3): 718. :10.1016/j.pathophys.2009.01.006 . PMID 19268550.

[9] Röösli, Martin (June 2008). "Radiofrequency electromagnetic field exposure and non-specific symptoms of ill health: A systematic review". Environmental Research 107 (2): 277-287.

[10] Wikipedia. Mobile Phone [Online]. Available at: http://en.wikipedia.org/wiki/Mobile_phone.

[11] WHO Fact Sheet 304: http://www.who.int/mediacentre/factsheets/fs304/en/index.htm. 